\title{
Effectuation and causation: Propositions about decision making process in business network environments
}

\author{
Anderson Queiroz Lemos ${ }^{1}$ Tales Andreassi ${ }^{2}$ \\ ${ }^{1}$ Escola de Administração de Empresas de São Paulo-FGV-EAESP, e-mail: andersonqadm@gmail.com \\ ${ }^{2}$ Escola de Administração de Empresas de São Paulo-FGV-EAESP, e-mail: tales.andreassi@fgv.br
}

KEYWORDS

Network.

Centrality.

Organizational structure.

Causation.

Effectuation.

Received 31.12.14

Revised 25.03.15

Accepted 06.04.15

DOI:10.7867/1980-4431.2015v20n1p29-43

ISSN $1980-4431$

Double-blind review

\section{ABSTRACT}

This theoretical essay focuses on the dichotomous question concerning whether entrepreneurs adopt Effectuation or Causation decision making models. Decision making is an important theme in the studies of entrepreneurship. However, these models have not been explored in the context of business network environments. Due this gap, this essay proposes to examine the possible effects of the centrality of the firm on its organizational structure, and this latter on the predominance of entrepreneur's Effectuation or Causation decision making in a business network environment. It is argued here that to the extent that the firm acquires relevant resources while enhances its centrality in the network, changes will take place in its organizational structure over time forcing the entrepreneur adopt Causation instead of Effectuation. Four propositions support this argument. Business networks are appropriated environments to find evidences of where and when entrepreneurs are more likely to adopt one or another decision making model. The potential practical implications of this study are described as follow: i) not all relations are equally important for the growth of the firm; ii) it is suitable for entrepreneurs use Effectuation model when the organizational structure is simple and resources are non-relevant; iii) it is recommended for entrepreneurs use Causation model in situations where failures could be critical to the growth of the firm. The theoretical framework focuses on the concept of inter-organizational networks, on the transformation of the organizational structure and on the principles of Effectuation and Causation.

\section{Introdução}

This theoretical essay focuses on the dichotomous question concerning whether entrepreneurs adopt Effectuation or Causation decision making models. This issue has not been explored either empirically or experimentally in business network environments (PERRY; CHANDLER; MARKOVA, 2012). In addition, the externalities caused by centrality of the firm in a business network environment have not been considered in recent researches on decision making processes (WOERTMAN, 2014).

Due these gaps, this theoretical essay proposes to examine the possible effects of the centrality of the firm on its organizational structure, and this latter on the predominance of entrepreneur's Effectuation or Causation decision making in a business network environment. Causation and Effectuation are different decision making models in their essences (SARASVATHY, 2001; READ; SARASVATHY, 2005). The former was developed along the theories of economy and strategic management for explaining how entrepreneurs use resources for guiding their decision making through a particular effect. The latter was developed by Sarasvathy (2001) based on previous researches of Knight (1921), Weick (1979), March (1982) and Mintzberg (1978, 1994), as an alternative approach for explaining the creation of artefacts in accordance with entrepreneur's experience and the lack of firm's resources. Here entrepreneur takes a set of means as given and selecting between possible effects that can be created with that set of means.

Different authors (SARASVATHY, 2001; 
DEW; SARASVATHY, 2002; KUPPER; BURKHART, 2009; GOEL; KARRI, 2006; WILTBANK, ET AL, 2009; DEW, ET AL., 2009) described Causation and Effectuation theoretical principles. Due both decision models are an integral part of human reason and may occur simultaneously, overwriting themselves, current efforts are striving to discover when one model is more adequate - not better - to be used (SARASVATHY, 2001). Read and Sarasvathy (2005) proposed entrepreneur's experience and firm's resources as dimensions to solve this issue. However, it is argued here that authors' model has limitations if studied in business network environments.

Business networks are important environments where companies relate to enhance their chances to acquire resources for survivor and growth (BALESTRIN; VERSCHOORE, 2008). Several studies have shown the benefits of centrality for the development and welfare of the organizations, and the organizational structure has already been used in previous studies (FLAMHOLTZ; DAS; TSUI, 1985) as a moderator variable over individual's behavior. Therefore, it is proposed here that to the extent that the firm acquires relevant resources while enhances its centrality in the network, changes will take place in the organizational structure of the firm over time forcing the entrepreneur adopt Causation instead of Effectuation decision making model. Four propositions support this argument. They promote a chance for future empirical studies find evidences of when and where entrepreneurs are more inclined to use Causation or Effectuation in business network environments.

The first part of this essay focuses on the concept of centrality, considering interorganizational business network as market where firms can acquire the necessary resources for the fulfilment of their objectives; then presents the changes that take place in the organizational structure of the firm when it interacts in the environment; finally presents the principles of Effectuation and Causation decision making models. The second part presents the argument and the propositions of the research. The last part of this study presents the final considerations with some potential practical implications for entrepreneurs.

\section{Theoretical Framework}

2.1 Inter-organizational Business Networks and the Benefits of Centrality

Network analysis is often used for exploring social and organizational themes (BALESTRIN; VARGAS, 2004; BALESTRIN; VERSCHOORE, 2008). Wasserman and Faust (1994) define social network as a finite set of actors and all the relations among them. By deriving this concept, inter- organizational network consists in a group of firms that are inter related, characterized by "relatively constant transactions, flows and connections that occur between two or more organizations in their environments" (OLIVER, 1990, p. 241).

Barney (1986) calls the place where the transit of resources occurs the "Market for Strategic Factors". For this theoretical essay, business networks are considered as market for strategic factors because they are environments where firms form their business connections and make all the necessary transactions for survival. Due to the diversity of tangible and intangible assets, resources are "anything that can be thought of as a strength or weakness of a particular enterprise" (WERNERFELT, 1984, p. 172).

The number of connections one actor have in a business network defines its centrality (NIEMINEN, 1974). Centrality ranges from zero (when there is no connections) to g-1, where $\mathrm{g}$ is the maximum number of connections one actor can have in the network (WASSERMAN; FAUST, 1994). So, one can deduce that actors with more connections are in the center of the network. Otherwise, those actors with few connections are in the periphery of the network or close to it.

Centrality is considered one of the most fundamental aspects of social network studies (FREEMAN, 1979). It "gives an understanding of the role of actors in the network environment, and is relevant in identifying key actors as well" (RIBEIRO; BASTOS, 2011, p. 283). Therefore, if one actor is more central than the others are, it means a synonym for visibility and potential for communication between individuals (SHAW, 1954).

The central actor is closer to others (WASSERMAN; FAUST, 1994), and its proximity gives advantage of independence, productivity and efficiency (BEAUCHAMP, 1965; FRIEDKIN, 1991). The centrality general proposition is that the actor with more connections in the network has more access over the flow of resources, then better results (HOANG; ANTONCIC, 2003).

Several studies show the benefits of centrality for the development and 'welfare' of the organization, for instance: performance in knowledge networks (TSAI, 2001); performance of new products during the formation of alliances between technology networks (SOH, 2003); independence and autonomy (BORGATTI, 2010); act as a gate keeper (OBSTFELD, 2005); political success (GALASKIEWICZ, 1979); investment strategy (RATCLIFF, 1980); participation in important decision-making processes (MILLER, 1980); attraction of additional suppliers of resources, knowledge and skills (SOH, 2010); coordination for troubleshooting (ANDREW; KEN- 
DRA, 2009).

Find out the centrality of one actor in a network is the initial observation that researchers must do (HANNEMAN; RIDDLE, 2005), the second step is analyze the externalities that it causes (BORGATTI, 2010). Due centrality promotes these benefits to the organizations, one can deduce that the relevance of resources transmitted through the relations may promote the changes that take place in the organizational structure over time.

\subsection{Organizational Structure and the Elements of its Complexity}

This session presents the horizontal, vertical, and geographical changes that take place in the organizational structure of the firm due the relevance of resources transmitted through close relations in the network. The first element of a firm's structure is its complexity. In simple terms, these three variations refer to the degree of depth, breadth and distribution of the complexity of the organizational structure (HALL, 2004).

Organizational structures are not statics systems. They undergo constant transformations, building up as their interaction with the environment (RANSON; HININGS; GREENWOOD, 1980). The variability of organizational structuring (the particular set of rules, differentiation of labor and hierarchy for each organization) happens because organizations cannot escape environmental contingencies (LAWRENCE; LORSCH, 1967).

The entrepreneur plays a particular relevant role in the transformation of the organizational structure. He is the link between the external environment and changes that take place in the organization (HILLS; LAFORGE, 1996). Its action to recognize opportunities leads to the establishment of structures for enabling satisfactory performance to the company (MELLO; LEÃO; PAIVA JUNIOR, 2006).

The adaptation of the organizational structure of the firm to meet environmental demands is not free of interest. The infrastructure of the environment has a certain pattern of available resources on which the organization has to count (RANSON; HININGS; GREENWOOD, 1980). It is not free of charge too. According to these authors, the supply of resources will force entrepreneurs create departments, hire people, introduce new processes, and so on.

One organizational structure definition suitable with this situation was that proposed by Blau (1974, p. 12), as "the distribution, among various lines, of persons among social positions that influence the relations among their roles". This means that organizations possess divisions of labor, employees have different tasks, and levels or hierarchies that establish how persons must perform their roles within (HALL, 2004).
Part of the general argument developed in this theoretical essay states that the distribution of relevant resources into the firm causes changes in its organizational structure, making it more complex. Of the elements of organizational complexity, horizontal and vertical differentiation and geographical dispersion are the most commonly perceived and studied (HALL, 2004).

The horizontal differentiation is one of the key elements of the complexity of the organizational structure (HUMMON, 1990), with specialization and departmentalization as its main characteristics (BILHIM, 1996). It can be accessed evaluating the number of individuals' occupational specialities and the time necessary for training in each of them. According to Hage (1965), the complexity of an organization is measured by the quantity of knowledge available in it.

The horizontal differentiation happens when tasks are divided among specialists and/or unskilled individuals (HALL, 2004). In the former group, tasks are delegated to highly trained persons, which have an extensive task to perform. According to Hall (2004) the division of labour among specialists is common in companies that perform a wide range of activities and which cater to customers that require this variety with quality, such as hospitals and universities. This kind of horizontal differentiation requires a high level of coordination of personal interests. For the unskilled individuals group, tasks are subdivided and delegated to a large number of employees ('McDonalization'), thus making problems simpler to resolve and control (RITZER, 1983). According to this author, 'McDonalization' refers to the contemporary forms of rationalization at work.

The vertical differentiation is another key element of the complexity of the organizational structure (HUMMON, 1990). It happens according to the proliferation of supervision levels. It can be measured by accessing the number of positions between the principal executive and the employees which work in production, or by the ratio between the total number of levels in all the divisions (areas, sectors) of the organization and the number of divisions (HALL, 2004).

The last aspect of organizational complexity is the geographical dispersion. This is characterised mainly by the distancing of members of the organization from the centres of power, i.e., where the main strategic decisions are taken. According to Hall (2004), geographical dispersion is relatively easy to evaluate and its measurement consists of counting the number of localities in which a firm possesses business units, or establishes a relation between the number of persons that work in and outside the head office. It is important to stress that this type of dispersion does not preclude that the previous types (horizontal and vertical) may occur simultaneously.

Revista de Negócios, v. 20, n. 1, p. 29-43, April, 2015. 


\subsection{Effectuation and Causation Decision Making Models}

Organizations are places with collections of choices looking for problems and decision makers looking for tasks (COHEN; MARCH; OLSEN, 1972). The decision maker represents the interests of the organization, with the entrepreneur as its most important agent (ANDERSON; DODD; JACK, 2012). In this sense, the entrepreneur has a broader meaning for the development of organizations (LANDSTRON; BENNER, 2011).

Decision making is the key element of entrepreneurship (KUCKERTZ, 2013), but "it is a mistake to consider decision making as a perfectly rational and calculated process. It is also a mistake to consider decision making as simply a random process" (HALL, 2004, p. 144). The notion that the decisions of entrepreneurs on how to recombine resources are creative and subjective, and not the role of objective forces, influencing the existence, identification and exploitation of opportunities, should be rejected (SHANE, 2012).

The dichotomous clash over the use of prediction and rationality versus intuition in the decision making process was described by March (1982) as the biggest challenge of normative theories of decision. The difficulty in solving this problem occurs because both rational and intuitive logics are integral parts of human reasoning, and they can overlap. This issue arises because people are constantly deciding whether or not to follow standardized routines (WEICK, 1979).

The most widely accepted argument is that there is no intention of wanting to prove that one single paradigm is better or more effective than the other is, because both can be used at appropriate moments (SARASVATHY, 2001). Hodgkinson and Starbuck (2008) claim that both rational causality and intuitive decisions have appropriate situations for use, and mistakes happen when decision makers adopt the wrong model.

When considering that a dichotomy in the

Table 1: Causation and Effectuation dimensions

Issue

Causal or Predictive Position

Effectual Position decision process exists, the researcher is accepting that a model of decision making cannot be complete if it does not consider non-predictive and predictive aspects. After all, there is no business plan or ideal competitive analysis for reducing the chances of businesses failing to achieve their goals (TASIC; ANDREASSI, 2008), and intuition is not the only sign of success (READ; SARASVATHY, 2005).

In other words, entrepreneurs may vary their strategies in everyday business using parts of each decision making logic, sometimes they will make decisions in a causal rationality manner and sometimes in an effectual rationality way. Causation and Effectuation emerge in this scenario as very different types of decision models in their characteristics (SARASVATHY, 2001; READ; SARASVATHY, 2005).

Accordingly to Sarasvathy (2001, p. 245) while "Causation process takes a particular effect as given and focus on selecting between means to create that effect. Effectuation is a process that takes a set of means as given and selecting between possible effects that can be created with that set of means". In a broader sense in the former there is an emphasis on prediction, and in the latter there are strategies that emphasize nonpredictive control (WILTBANK ET AL., 2009).

Table 1 summarizes the dimensions of Causation and Effectuation decision making models for six different issues. While the former was developed along the theories of economy and strategic management for explaining how entrepreneurs use resources for guiding their decision making. The latter was developed by Sarasvathy (2001) based on previous researches of Knight (1921), Weick (1979), March (1982) and Mintzberg $(1978,1994)$, as an alternative approach for explaining artefacts creation in accordance with entrepreneur's experience and the lack of firm's resources.

\footnotetext{
View of the Future

Prediction. The causal approach views the future as a continuation of

the past that can be acceptably and usefully predicted.

Should. Commit as a course of maximizing, analysis, and what should he done.

Creation. The effectual approach views the future as contingent on actions by willful agents, largely nonexistent and a residual of actions taken. Prediction is unimportant us a result.

Can. The effectual approach is to do what you can (what you are able to do) rather than what your prediction says you should.
} 
Basis for Taking Action And Acquiring Stakeholders

Planning

Predisposition Toward Risk

Attitude Toward Outside Firms
Goals. The causal approach is to let goals determine sub-goals.

Commitment to particular sub-goals determined by larger goal constrained

by means. Goals determine actions, including individuals brought on board.

Commitment. Path selection is limited to those that support a commitment to an existing goal.

Expected Return. The causal approach is to pursue the (risk adjusted) maximum opportunity, but not focus on downside risk.

Competition. The causal approach is

to be concerned with competition and

constrain task relationships with customers and suppliers to just what

is necessary.
Means. Actions emerge from means and

imagination. Stakeholder commitments and actions lead to specific sub-goals. Feedback from achievement/non-achievement of subgoals lead to design of major goals.

Contingency. Paths are chosen that allow more possible options later in the process, enabling strategy shift as necessary.

Affordable Loss. The effectual approach is to not risk more than can afford to be lost. Here, the calculation is focused on the downside potential.

Partnership (pre-set engagements). The effectual approach is to create a market jointly, building your market together with customers, suppliers and even prospective competitors.
Source: Read and Sarasvathy (2005).

Within the dynamics of social science research, causation is defined as "the operation that allows something (event, effect, condition, fact) to happen under certain determined theoretical conditions" (BRUYNE; HERMAN; SCHOUTHEETE, 1991, p. 164). Causation characteristics (table 1) state that entrepreneur's decision making is driven by project targets, guided by expected returns, identified uncertainties are avoided through analyses of the market and competitors, contingences are avoided in order to achieve project targets, and trends are exploited by the use of forecasts (KUPPER; BURKHART, 2009).

Economic and management theories usually concentrate on rational decision making model (VENKATARAMAN; SARASVATHY, 2001; CHANDLER ET AL., 2011). There is an historical reasoning that explains the entrepreneurs' importance attributed to clear and well defined targets, bases and formal designs or revisions and other factors that are accessible in the construction of new projects or any other artefact. Ghemawat (2002) states that rational and causal thinking were strengthened in the post-war period, "which encouraged managers' attitudes to use the formal strategic thinking to guide business decisions" (p.13).

On the other hand Effectuation is the essence of a new theoretical approach, albeit still rudimentary, developed by Sarasvathy (2001) for explaining de creation of artefacts in the absence of resources. Here opportunities need to be constantly created by human efforts, and there is no predictive control over the future, which means that if a person can control the future, there is no need to foresee it (SARASVATHY, 2001; DEW; SARASVATHY, 2007). It sheds light on the idea that the development of products does not require the notion of concepts that are related to causality or determinism, but the success of the entrepreneur derives from the means available in the environment for accepting risks, and from the use of imagination as it puts models into effect and produces new products (SARASVATHY, 2001).

In the Effectuation model, the success of an enterprise does not depend on business plans or competitive analysis, but on the control of the means (resources) owned by the company and by the entrepreneur. At the enterprise level, the corresponding means are physical, human and organizational resources. At the individual level, there are three categories of means whose control can generate organizational success: entrepreneurs must know themselves, i.e., their own characteristics, preferences and abilities, what entrepreneurs know, i.e., the information and knowledge possessed (previous industry experience and/or formal knowledge), and finally who the entrepreneurs know, i.e., the social network to which he/ she belongs (SARASVATHY, 2001).

Despite all characteristics summarized in Table 1, Chandler et al., (2011) verified that Effectuation and Causation are in fact formative constructs. They found that trial, acceptable losses, flexibility, and pre-set engagements are dimensions for Effectuation, and that Causation is a single dimensional construct with seven items (preset engagements as well) that represent the actions of a rational causal paradigm in the sense of being able to lead organizations to the best possible outcome. In a rational process, cause and effect are the operative logic itself (WILTBANK ET AL., 2009). Causation construct represent the importance given to clear and well defined targets, and/or reviews of formal projects and other variables that are not accessible to entrepreneurs during 
the construction of new artefacts.

The Effectuation contribution as a nascent theory goes beyond simply being a way that is opposite to the rational logic of cause and effect to explain the decision making process, "effectuation is useful in situations where there is no predefined universe of possibilities to explore - instead, a universe is created, often unintentionally, by acts of human imagination" (VENKATARAMAN; SARASVATHY, 2001, p. 15).

\section{Research Argument}

Although Effectuation and Causation are not mutually exclusive, i.e., entrepreneurs can take decisions based as much on causal as on effectual models, both are located on the opposite sides of a continuum. This essay intends to help resolve when one is more appropriate than the other by linking the concept of centrality, the relevance of resources obtained by economic and social ties, and also the elements of organizational structure complexity. This section presents the general argument and the propositions of the research.

The prior focus is on that of Read and Sarasvathy's (2005) model (FIGURE 1). These authors suggest firms' resources (as moderating variable) and entrepreneurs' experience to explain when
Causation and Effectuation are more appropriate to be used. Indeed these dimensions are necessary for explaining entrepreneurs' actions in the face of environmental uncertainty (SCHLÜTER ET AL., 2011). While experience is an important micro foundation of entrepreneurship for explaining how individuals perceive opportunities and develop artefacts (ZAHRA; WHITE, 2011), the lack of resources is the basis of Effectuation model (SARASVATHY, 2001).

In Figure 1, proposition P1 states that "Although novices may vary in their use of causal and effectual action, their preferences for Effectuation in the early stages of new ventures will increase as they become experts". Furthermore, "both highly causal and highly effectual novices learn to balance causal and effectual approaches during the growth phase of new ventures, before developing a clear preference for highly effectual strategies as their expertise grows". Proposition P2 states "the more resources available to novices, the more causal their actions are likely to be. In the case of expert entrepreneurs, availability of resources will not affect their use of highly effectual action". Propositions P3 and P4 explain the change in the decision making process toward the logic of Causation as far as the company grows. Both are agreed, so will not be commented.

Figure 1: Relationship between causal/effectual logic and the life-cycle of firms and entrepreneurs

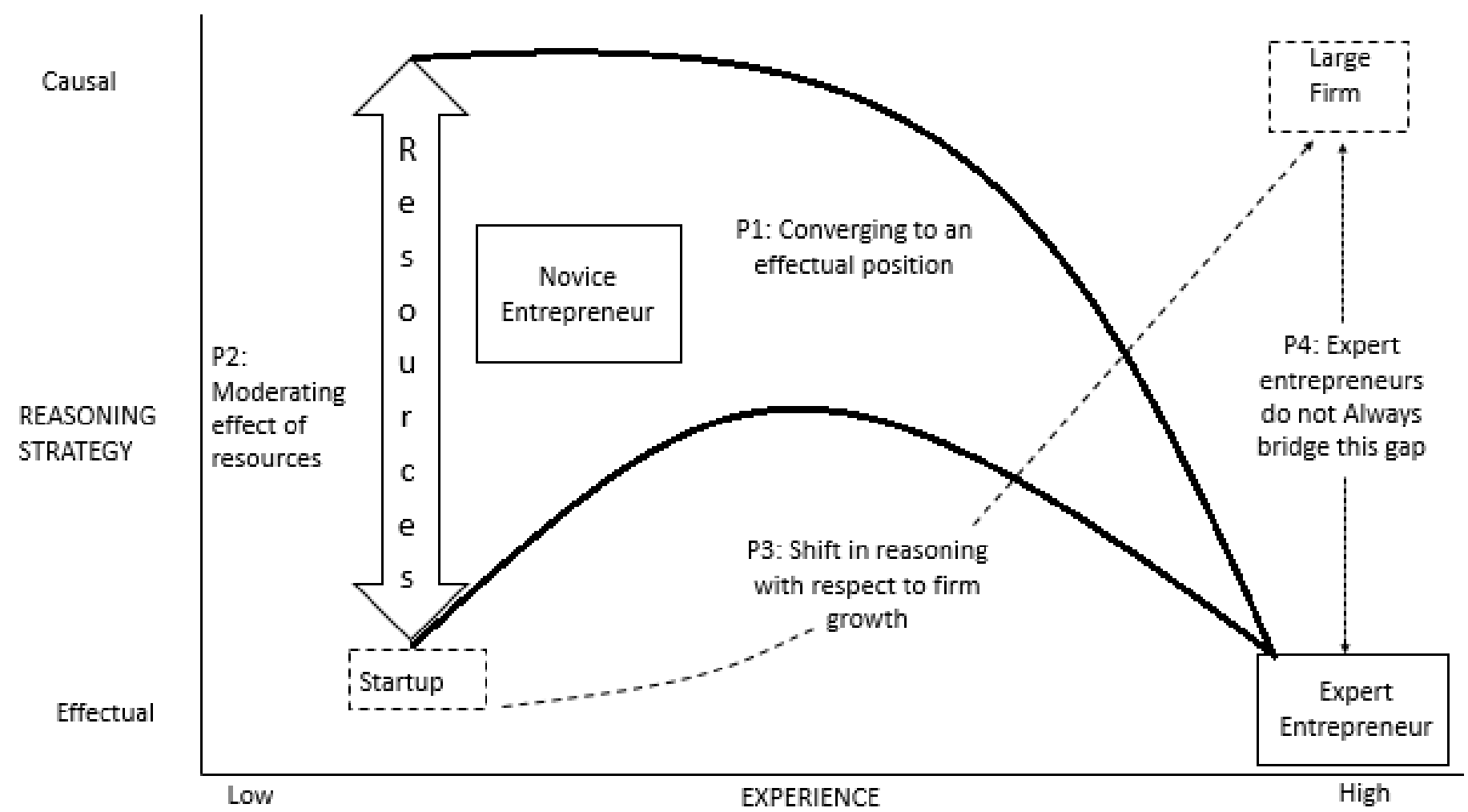

Source: Model from Read and Sarasvathy (2005). 
However, there are some considerations about propositions $\mathrm{P} 1$ and $\mathrm{P} 2$. Here it is argued that firms' resources and entrepreneurs' experience are not sufficient means to explain the prevalence of Causation or Effectuation decision making models when business network is the operational environment. Here the notion is defended that even if entrepreneurs become experts, Effectuation characteristics will not persist in time when the firm strives for get a central position while access relevant resources and develops its organizational structure. Here the theory is to extent that entrepreneurs become experts and their firms grow in time, their preferences for Causation will increase. The theory is also defended that in the case of expert entrepreneurs, availability of resources will affect their use of highly effectual action and transform it into a causal action.

Figure 2 illustrates externalities promoted by centrality over organizational structure, and this latter on the predominance of the decision making model. Due to businesses growth and develop- ment depends on capital (SILVA, 1985) and intangible assets accumulation (BARROSO; GOMES, 1999; UHRY; BULGACOV, 2002; DANTAS; BELL, 2011), one can deduce that the importance of resources accessed through organizational ties promotes high or low changes in the complexity of organizational structure in a vertical, horizontal and/or in a geographical way.

Despite Read and Sarasvathy's (2005) arguement that firm's resources are mechanism for moderating decision making, Simon (1997) states that there is a closer relationship between organizational structure and decision making process. The organizational structure was used in previous studies (FLAMHOLTZ; DAS; TSUI, 1985) as a moderator variable over individual's behavior. The theory states that its role is to avoid random behaviour of individuals (WEBER, 1947), in other words, it is to regulate the effects of the individual's interests on the interests of the shareholders (HALL, 2004).

Figure 2: Conceptual model of the study.

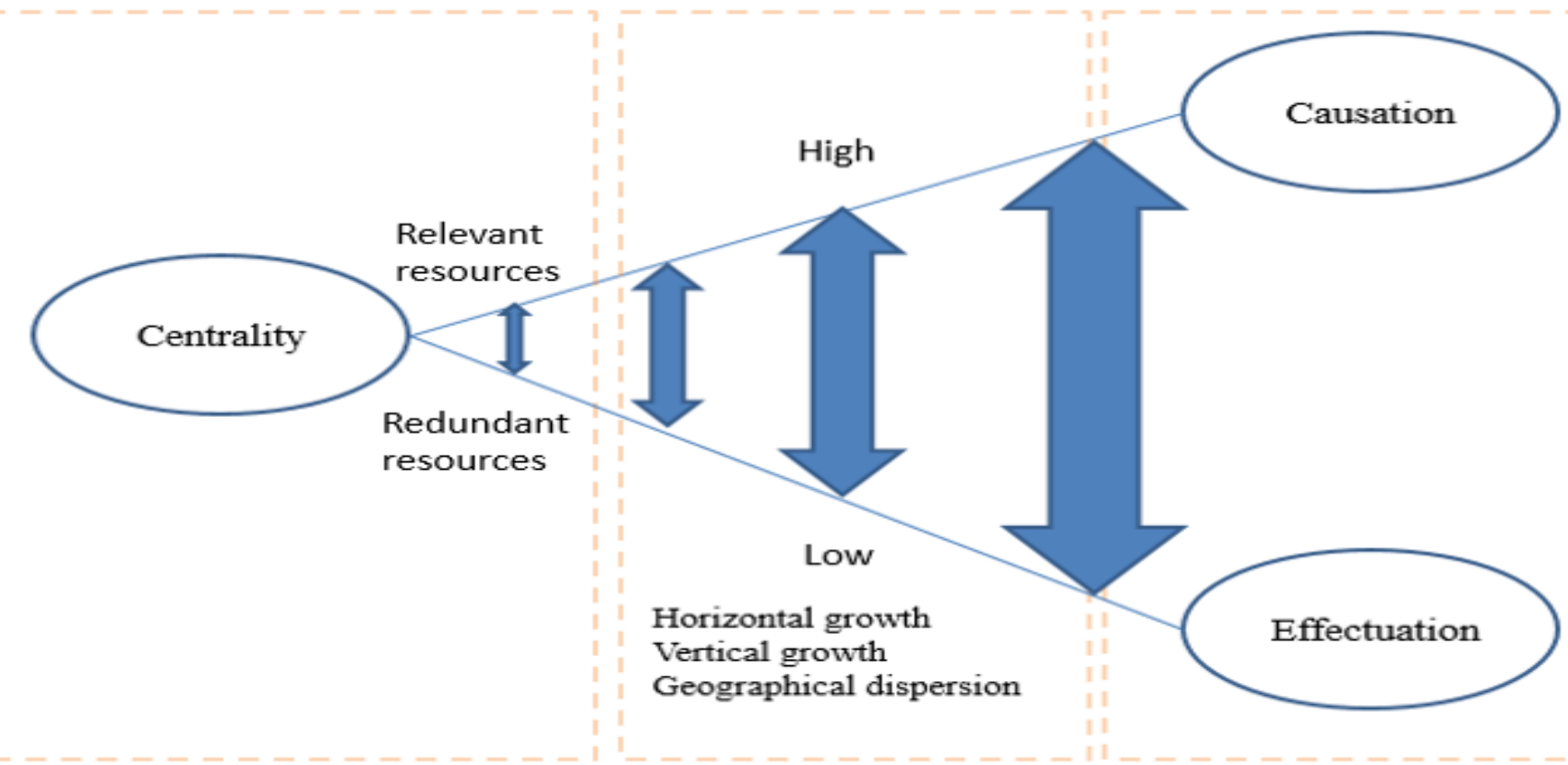

Source: Elaborated by the authors

In this sense, while modifications to organizational structure may occur, control mechanisms will start working limiting decision makers adopt Effectuation actions. Therefore, firms with a more complex organizational structure the Causation decision making model becomes typical. Otherwise, firms with simple organizational structures control mechanisms will be not necessary, therefore null or negligible, justifying the use of the Effectuation model. Four propositions support this argument.

\section{Propositions}

Understanding the effects caused by firm's centrality concerning the choices and behaviours of the organization itself is one of the goals of network theorizing (BORGATTI, 2010). The first observation researchers should make in studying networks is finding the centrality of the researched object in the network, whether individuals or organizations (HANNEMAN; RIDDLE, 2005). Equally important is the analysis of externalities caused by centrality on the behaviour of organizations (BORGATTI, 2010).

An actor with relative centrality can enjoy the greatest function of social networks, i.e., receiving the flow of resources available in the envi- 
ronment before other actors (BORGATTI, 2010). However, the relevance of centrality for the purposes of the organization is related to the types of links it generates in the network and the relevance of resources transmitted by them.

The simple definition of centrality is criticized for being vague about the nature of relationships (BLIEMEL; MAINE, 2008). Therefore, can be difficult to researchers answer if it is advantageous for a person to be the center of a social network or for a company to be the most central point in an inter-organizational network level, without taking into account the perspective on what makes the actor be central.

Jen (2013) showed that the centrality could have different effects on the actor's welfare. According to him, if the network of relationships is conflicting, the impact on job satisfaction is negative. Otherwise, if the network is challenging then the actor's centrality could has a positive impact on its satisfaction and welfare. Burt (1992) states that if an actor is located in a very central part of a redundant network that can be a burden. Otherwise, if the actor is in the same position in a heterogeneous network it can receive completely new and relevant information.

It means that the usefulness of the centrality depends on the relevance of resources transferred through ties. Burt (1992) proposed a type of connection - the concept of bridging ties arises - related to economic interests and a strategic and instrumental view of relations. In bridging ties the bonds are not accidental, but purposely useful, and so they are intentionally sought. Bridging ties permit fill structural holes when an actor makes a connection with other distinct clusters.

A bridging tie is defined as a tie that fills the voids between groups of contacts (Burt, 1992). Borgatti (2010, p. 11) defines it as "a tie that connects a person to someone who is not connected to its other friends". This means that only one person in the group maintains contact with others outside, so this person who keeps the tie will have exclusive access to information that others do not have.

Bridging ties create bridges between different groups of contacts - through email correspondence, telephone conversations, sales transactions or formal contracts - allowing them time to time receive new information and resources. This type of tie aids firms in the perception of business opportunities. According to Tiwana (2008, p. 251 ), "the greater the extent of bridging ties in an alliance between groups, the greater the diversity of accessible knowledge, skills and perspectives that a contact can have on the network".

As the type of tie that actually promotes access to non-redundant features is the bridging one (TIWANA, 2008; BORGATTI, 2010), one can infer that every time a company has new contacts through this type of tie, it means that it has ac- quired a centrality that promotes more autonomy to transit across the network and access to new resources. When these resources are considered relevant by the entrepreneur for the growth and development of the firm, they may require changes in the organizational activities of the companies, such as in the division and distribution of work, tasks, or occupied hierarchical positions, i.e., in the differentiation of tasks (RANSON, HININGS; GREENWOOD, 1980).

The organizational structure changes because more relevant resources are transacted, and to manage them more skilled people are hired, more departments and hierarchical levels are created, more business units are opened, and more administrative intensity is generated. Therefore, the way in which organizational structure is formatted depends on the centrality of the company in the network, but on the increases of the resources transacted with its stakeholders. Thus, the first proposition of this study states that:

Proposition 1: Centrality contributes for a complex organizational structure when resources are accessed through bridging ties.

Whereas the focus of bridging ties is economic and the main feature is its non-redundancy in the resources transacted (MCEVILY; ZAHEER, 1999), the focus of studies about social embeddedness entails strong ties (LAVIE, 2007). According to Granovetter (1973), the characteristics of strong ties are long time spent by individual in interactions, high intensity and emotional intimacy involved, and mutual assistance capacity. Because of the high intensity presented in the relations, "people tend to have similar social attributes such as education, income, occupation and age" (BURT, 1992, p. 16).

Strong ties can be understood as follows: people who live in a group of close contacts have strong relationships, and all information flows quickly and continuously for this group, so that everyone knows about everything that happens. This capability occurs because individuals share truth, reciprocity, trust, legitimacy and proximity in their interaction (TIWANA, 2008).

Granovetter (1973) reasons that strong ties are not likely to be a source of new information, therefore cannot form bridges to fill structural holes (BORGATTI, 2010). The lack of information occurs because individuals are aloof and because of their partners' incapability to generate new information. In other words, the relationships are not good enough to promote new and valuable information and resources.

Accordingly to Burt (1992), the force on the social relationship between these individuals will connect one to another, providing the same network benefits. The smaller the network between 
individuals with the same contacts, the more redundant the network will be. Simple examples are "the relationship between father and son, brother and sister, husband and wife, close friends, people who have been partners for a long time, people who frequently get together for social occasions, and so on" (p. 18).

The particularity of the strong ties is that if the relationship between firms are extremely strong they will have much capacity to implement actions, but on the other hand will not have the capacity to create them, meaning no innovation (TIWANA, 2008). In other words, the firms of the network connected by this tie have legitimacy to execute the action, but have difficulty in planning it.

According to (Burt, 1992, p. 12), "whatever the source for strong relationships between socially similar people, it is expected that the resources and opinions of an individual will be correlated with the resources and the opinions of its close contacts". Accordingly, the redundancy happens because companies are saturated of themselves and their partners, and the actors are susceptible to produce information "superfluous and uninspired" (MCEVILY; ZAHEER, 1999, p. 1138). Previous researches have empirically demonstrated that strong ties were not significant for the growth of firms. By studying 1600 German companies, Bruderl and Preisendorfer (1998) found evidences that strong ties were more important for the survival of the firms than for growth in sales.

By the economic perspective of firm's nature purposed by Coase (1937), companies grow in time when they make additional transactions. Once again, if the resources transmitted through relations in a network are redundant, the centrality of the firm will not affect its growth nor its development. Without important resources for managing, there are probably no modifications in the complexity of the organizational structure in any direction. Therefore, the second proposition of the study states that:

Proposition 2: Centrality does not contributes for a complex organizational structure when resources accessed through strong ties.

Many organizations begin their activities with few resources, products and services in a single location (SILVA, 1985), "even large corporations start as small startups" (GRANT, 2003, p.147). The most suitable configuration model for small companies is having a simple organizational structure (SILVA, 2004), which means simple horizontal and vertical differentiation and probably no geographical distribution.

When the firm operates through simple organizational structures, managers do not accomplish planning nor employee training
(MINTZBERG, 1979). They also "do not have the time or detachment to clearly express the exact nature of their needs" (PADULA; VADON, 1996, p. 33). During this time - without policies, explicit goals, nor strategic or operational planning (PADULA; VADON, 1996) - important aspects of intuitive logic will be preserved during the decision making process, as the use of imagination for example (READ; SARASVATHY, 2005).

The vast majority of entrepreneurs running small companies do not use any form of data analysis for decision making (LIMA; IMONIANA, 2008), "being that the management of these companies is often done intuitively" (p. 29). This affirmation is in accordance with the belief that with each passing day emerging entrepreneurs are guided by feelings of what they are able to do with lack of resources, using intuition, experience and personal values, i.e., the emerging result of the actions is in the mind of the entrepreneur (SARASVATHY, 2001; ANDRADE; ALYRIO; MACEDO, 2004).

There is nothing more subjective than run a business based on ideology, feeling and emotions, personal values (SIMON, 1947), and creativity as well (BUCHANAN; VANBERG, 1991). With a simple organizational structure, important aspects of entrepreneurs' intuitive logic and their expectations will be preserved during decision making process (PADULA; VADON, 1996), which make the decision process closer the Effectuation model.

In simple structures planning is contingent and the entrepreneur can chooses paths that allows change strategy whenever necessary (READ; SARASVATHY, 2005). With a simple organizational structure, is argued here that dimensions proposed by Chandler et al., (2011) for Effectuation model are more evident. It means that entrepreneur can be flexible to adapt strategies according to the environment contingencies and thus change the course of future events (CHANDLER ET AL., 2011).

In small firms with simple organizational structure decisions are deeply centered on the owner who is the most important agent (LAKATOS, 1997). Entrepreneurs' agency are constant (MINTZBERG; QUINN, 1996), as well as in Effectuation model (SARASVATHY, 2001). Therefore, they are able to try many different management models until find one suitable enough for manage their organizations (CHANDLER ET AL., 2011).

In Effectuation model entrepreneurs can decide how much they are willingness to lose (SARASVATHY; KOTHA, 2001). Due small firms have few relevant resources and simple organizational structures, entrepreneurs have not much to lose making wrong decisions and risk acceptance is high as well (SARASVATHY, 2001).

Revista de Negócios, v. 20, n. 1, p. 29-43, April, 2015. 
So, one can deduce that even if decision makers become experts in time - as stated by Read and Sarasvathy (2005) - their preferences for adopting the model of Effectuation will increase while the company has a simple organizational structure.

Therefore, the third proposition of this essay states that:

Proposition 3: In companies with simple organizational structures, Effectuation model will be predominant in the decision making process.

As new resources enter the firm, it gets bigger horizontally, vertically and/or geographically. According to Padula and Vadon (1996, p. 35), "the company's own success creates new sets of problems and challenges to their survival. (...) mainly because of its growth in size and complexity of activities". The Brazilian Aeronautics Company (EMBRAER), for example, has complex projects that combine planning, organization and the use of appropriate tools (GIACOMETTI ET AL., 2007), where "all the decisions made must be grounded based on what is wanted to achieve for the product being developed, such as cost, quality, timeliness, logistics and environment" (p.600).

Ranson, Hinings and Greenwood (1980) state that an efficient management will require differentiation in individual functions and control mechanisms through an elaborate network of rules and procedures. The organizational structure and its control mechanisms, such as strategic planning (MINTZBERG, 1994), formalization (PUGH, ET. AL 1968), centralization (BRESSER PEREIRA, 1963), socialization (GIBSON; IVANCEVICH; DONELLY, 1988), and reward (ETZIONI, 1964) can work as moderating mechanisms for inducing entrepreneurs adopt Causation decision making model.

According to (MINTZBERG, 1994), planning in organizations such as programs, schedules, budgets and other control mechanisms, "can serve as an early media to communicate the intentions of the strategy and to control individual interests, to the extent that a common direction is more important than individual free will" (p. 112-113). The most obvious reason for using planning is to ensure that everyone in the organization is moving in the same direction, and the best explanation for establishing normative techniques for developing strategies in organizations is that they reduce the power of managers in the formulation of strategies (MINTZBERG, 1994),

For organizations exercise their functions, their processes have to be integrated through mechanisms / control tools (CAMPS; LUCAARONAS, 2009). Since the studies conducted by Aston Group in the 1960s about the relationship between technology, size and environment in shaping organizational structure (PUGH ET AL.
1968; PUGH; HICKSON; HININGS, 1969), centralization and formalization have been used as control mechanisms in complex organizations.

According to Pereira (1963), in highly centralized organizations the most tactical and strategic decisions are reserved for strategic cupola, "so that the consistency of decisions and coordination are preserved (p.73)". Some studies show that a formalized organizational structure can lead to inflexibility and slowness in decision making process (BAUM; WALLY, 2003), as well as limitations on the speed of promoting innovation in the development new artefacts (BROWN; EISENHARDT, 2004).

The organizational socialization and the reward are also manners of obtain control over the behavior and thinking of individuals. While the former uses informal mechanisms such as culture and symbols (CÂMARA, 2012), principles and guidelines (GRANT, 2013), assumptions values and attitudes (SCHEIN, 1992), and informal language (KOTTER, 1982), the latter is a kind of remunerative power "based on control of material resources, such as salaries, commissions, so on" (SERGEANT; FERES, 1972, p.100).

Coordination and control discourage employees' freedom to put into practice the improvement of processes, products and services in response to opportunities that have been identified (HODGKISON; STARBUCK, 2008). Control is an attempt to increase the probability that people will behave in a manner to achieve the organizational objectives (FLAMHOLTZ; DAS; TSUI, 1985). Empirical evidences proved relationship between intrapreneurship and formal control. Zahra (1996) found that over-formal control is a disincentive to the development of entrepreneurship within a company.

Previous research has demonstrated the effects that the growth of organizational structure has on decision making process. Mintzberg and Waters $(1982,1984)$ found evidences that in so far as organizations in the food retail chain and women's underwear industry grew and became more formal, the future visions of managers became more rational (planned and programmed) while the flexibility and adaptability became less and less in evidence.

Tasic and Andreassi (2008) studied the case of a technology company that compares prices of products for sale on Internet. They found that the events surrounding the decision making process at the beginning of the company's activities were explained by the logic of Effectuation. To the extent that the company has grown in size, the causal rationality has become more evident in the decision making processes.

As stated earlier, the logic of Causation cannot be assumed to be unique and exclusive in the decision making process (READ; SARAS- 
VATHY, 2005). However, to the extent the firm's organizational structure grows - horizontally, vertically and/or geographically - entrepreneurs will have no reasons to use the Effectuation model (READ; SARASVATHY, 2005), especially in situations where failures are catastrophic (MAINE; SOH; DOS SANTOS, 2014). The liberty for managers' use trial, their capability for high acceptable losses, flexibility and excessive risk acceptance while managing their firm, will be retained in the organizational structure due its control mechanisms. Therefore, decision makers will be forced to adopt the Causation decision making process.

Proposition 4: In companies with more complex organizational structures, causation model will be predominant in the decision making process.

\section{Final Considerations and Practical Implica- tions}

This theoretical essay focuses on the dichotomous question concerning whether entrepreneurs adopt Effectuation or Causation decision making models while manage their businesses. The conceptual model proposed by Read and Sarasvathy (2005) was used as an inspiration for this study because it purposes a bridge to the problem of entrepreneurs' dichotomy in the decision making process. However, the effects of the centrality of the firm over its organizational structure, and this latter on the predominance of decision making logics has yet to be explored.

The whole argument built along this essay suggests that although entrepreneurs are able to adopt Causation and/or Effectuation in the early stages their firms, causation logic is proposed to explain the decision making process mainly of firms with relevant resources and a high levels of complexity in their organizational structure. On the other hand, companies with non-relevant resources for managing will have entrepreneurs running their business adopting Effectuation model. In turn, the effects caused by the bridging and strong ties on the vertical, horizontal and/or geographical growth of the organizational structure, will define the most appropriated decision making model to be used.

In considering a business network environment as a market, this theoretical essay developed the argument that bridging ties and strong ties are useful to connect firms providing them access to resources. Therefore, centrality by itself is not an important dimension for defining when entrepreneurs will adopt Causation or Effectuation without taking into account what makes the firms central.

Said that, business networks are appropriat- ed environments to find evidences of where and when entrepreneurs are more likely to adopt the Effectuation or Causation decision making models. Where, because to extent that the firms makes new connections and arises its centrality in the business network environment, it is feasible to locate its positions in the network at the time that evidences of these decision models arise. When, because not all new close relations will generate externalities on how entrepreneurs manage the business (ALDRICH; ZIMMER, 1986). Which means that organizational structure will change in accordance with the importance of contents transmitted through ties in the relations.

This theoretical essay has potential practical implications for entrepreneurs who manage their firms in a business network environment. The first one is that not all relations in the network are important for the growth and development of the firm. The second one is that it is suitable for them use Effectuation decision making model when the organizational structure is simple, saving time while chases opportunities. The third one is that it is recommended the use of Causation model when in situations where failures in the decision making could be critical to the growth of the firm.

Effectuation still a new theory. In these terms, a theory with few stages of development has has hardly any developed paradigms (KUHN, 1996). Researchers could test the four propositions developed in this theoretical essay using the bridging and strong ties scale developed by Tiwana (2008). It is suggested the use of measurement forms proposed in the section 2.2. Researchers could find when centrality is important for the growth of organizational structure. They also could use the Effectuation and Causation scale developed by Chandler et al., (2011).

\section{References}

AHUJA, G.; POLIDORO JR, F.; MITCHELL, W. Structural homophily or social asymmetry? The formation of alliances by poorly embedded firms. Strategic Management Journal, 30, p. 941-958, 2009.

ALDRICH, H.; ZIMMER, C. Entrepreneurship through social networks. In: R. Smilor and D. Sexton (Eds). The Art and Science of Entrepreneurship, p. 3-23, 1986.

ANDERSON, A, R.; DODD, S. D.; JACK, S. L. Entrepreneurship as connecting: some implications for theorising and practice. Management Decision, 50 (5), p. 958-971, 2012.

ANDRADE，R. O. B.; ALYRIO, R. D.; MACEDO, M. A. S. Principles of trading: Tools and management. São Paulo: Atlas, 2014.

ANDREW, S. A. Regional integration through contracting networks: An empirical analysis of institutional collection action framework. 
Urban Affairs Review, 44, p. 378- 402, 2009.

ANTONCIC, B. Organizational processes in intrapreneurship: A conceptual integration. Journal of Enterprising Culture, 9(2), p. 221-235, 2001.

BALESTRIN, A.; VERSCHOORE, J. Cooperation business networks: Management strategies in the new economy. Porto Alegre: Bookman, 2008.

BALESTRIN, A.; VARGAS, L. M. The strategic dimension of SME's horizontal networks: theory and evidences. Revista de Administração Contemporânea. Special issue, p. 203-227, 2004.

BARNEY, J. B. Organizational culture: Can it be a source of sustained competitive advantage? Academy of Management Review, 11, p. 65665, 1986.

BARroso, A. C. O.; GOMES, E. B. P. Tentando entender a gestão do conhecimento. RAP, 2, p. 147-70, 1999.

BASS, B. M. Organizational decision making. Illinois: Homewood, 1983.

BAUM J. R.; WALLY S. Strategic decision speed and firm performance. Strategic Management Journal, 24, p. 1107- 1129, 2003.

BEAUCHAMP, M. A. An improved index of centrality. Behavioral Science, 10, p.161-163, 1965.

BESANKO, D.; DRANOVE, D.; SHANLEY, M.; SCHAEFER, S. Economy of strategy, $5^{\text {a }}$ ed, Bookman, 2010.

BILHIM, J. Organizational Theory: Structures and people. Lisboa: ISCSP, 1996.

BLAU, P. M. On the nature of organization. Nova York, john Wiley, 1974.

BLIEMEL, M. J.; MAINE, E. M. A. Network embeddedness as a predictor of performance for New Technology-Based Firms. Int. J. Technoentrepreneurship, 1 (3), p.313-341, 2008.

BORGATTI, S. Strength of week ties, structural holes, closure and small worlds, 2010. Available in < http://www.analytictech.com/mgt780/ slides/swt.pdf $>$ accessed in Aug. 28, 2012.

BRESSER PEREIRA, L. C. Centralization and descentralization. In Prestes Motta e Bresser Pereira (1963/1980). Originaly Published as a handout, São Paulo, Fundação Getulio Vargas, Escola de Administração de Empresas de São Paulo, 1963.

BROWN, S. L.; EISENHARDT, K. M. Competitive strategy on the edge: a dynamic vision for corporate transformations. São Paulo: Cultrix, 2004.

BUCHANAN, J, M.; VANBERG, V. J. The Market as a creative process. Economics and Philosophy, 7 (02), p.167- 86, 1991.

BRUDERL, J.; PREISENDORFER, P. Network support and success of newly founded businesses. Small Business Economics, 10, p. 213225, 1998.
BRUYNE, P.; HERMAN, J.; SCHOUTHEETE, M. Dynamics of social science research. Rio de Janeiro: Francisco Alves, 1991.

BURT, R. S. Structural holes: the social structure of competition. Cambridge: Harvard University Press, 1992.

CABLE, D. M.; Shane, S. A prisioner's dilemma approach to entrepreneur-venture capitalist relationships. Academy of Management Review, 22 (1), p. 142-176, 1997.

CÂMARA, A. A. Case Study: The role of organizational culture in the integration and socialization of the organization's members. Revista Interdisciplinar Científica Aplicada, Blumenau, 6 (4), p. 80-97, 2012.

CAMPS, J.; LUNA-AROCAS, R. High involvement work practices and firm performance. The Intemational Journal of Human Resource Management, 20, (5), p. 1056-1077, 2009.

CHANDLER, G. N.; DETIENNE, D. R.; MCKELVIE, A.; MUMFORD, T.V. Causation and effectuation processes: A validation study. Journal of Business Venturing, 26, p. 375-390, 2011.

COASE, R. H. The Nature of the Firm. Economica, New Series, 4 (16): 386-405, 1937.

COHEN, M. D.; MARCH, J, G.; OLSEN, J. P. A Garbage Can Model of Organizational Choice. In: Administrative Science Quarterly. 17, p. 1-25, 1972.

DANTAS, E.; BELL, M. The co-evolution of firm-centered knowledge networks and capabilities in late industrializing countries: The case of Petrobras in the offshore oil innovation system in Brazil. World Development, 39 (9), p. 1570-1591, 2011.

DEW, N.; SARASVATHY, S. D. Innovations, stakeholders \& entrepreneurship. Joumal of Business Ethics, 74, p. 267-283, 2007.

DEW, N.; READ, S.; SARASVATHY, S. D.; WILTBANK, R. Effectual versus predictive logics in entrepreneurial decision-making: Differences between experts and novices. Joumal of Business Venturing, 24(4), p. 287-309, 2009.

ETZIONI, A. Organizações Modemas. São Paulo: Pioneira, 1964.

FLAMHOLTZ, E. G.; DAS, T. K.; TSUI, A. $\mathrm{S}$. Toward an integrative framework of organizational control. Accounting, Organizations and Society, 10 , p. $35-50,1985$.

FREEMAN, E. R. Strategic management A Stakeholder approach. London: Pitman Publishing, 1984.

FREEMAN, L. C. Centrality in social networks: Conceptual clarification. Social Networks, 1, p. 215 - 239, 1978/1979.

FRIEDKIN, N. E. Theoretical foundations for centrality measures. A.SS, 96 (6), p. 1478 1504, 1991.

GALASKIEWICZ, J. Exchange networks 
and community politics. Beverly Hills: Sage, 1979.

GIACOMETTI et al. Aplicação do earned value em projetos complexos - um estudo de caso na EMBRAER. Gestão \& Produção, São Carlos, 14 (3), p. 595-607, 2007.

GIBSON, J. L.; IVANCEVICH, J. M.; DONNELLY, J. H. Organizações: Comportamento, estrutura, processos. São Paulo: Atlas, 1988.

GHEMAWAT, P. Competition and business strategy in historical perspective. Business History Review, 76 (1), p. 37-74, 2002.

GRANOVETTER, M. S. The strength of weak ties. American Journal of Sociology, 78 (6), p. 1360-1380, 1973.

GOEL, S.; KARRI, R. Entrepreneurs, effectual logic, and over-trust. Entrepreneurship Theory and Practice, 30, p. 477-493, 2006.

GRANT, M. Contemporary strategic analysis, Blackwell, Oxford, 2013.

HAGE, J. An axiomatic theory of organizations. Admin. Sci. Q, 8-289, 1965.

HALL, R. H. Organization: structures, processes and outcomes. 8. Ed. São Paulo: Prentice Hall, 2004.

HANNEMAN, R. A.; RIDDLE, $M$. Introduction to social network methods. Riverside, CA: University of California, Riverside (published in digital form at http:// faculty.ucr.edu/ hanneman), 2005.

HILLMAN, A.; KEIN, G. Shareholder value, stakeholder management, and social issues: What's the bottom line? Strategic Management Journal, 22, p. 125-139, 2001.

HILLS, G.; LAFORGE, R. W. Marketing and entrepreneurship. Chicago: University of Illinois, 1996.

HOANG, H.; ANTONCIC, B. Networkbased research in entrepreneurship a critical review. Joumal of Business Venturing, 18, p. 165187, 2003.

HODGKINSON, G. P.; STARBUCK, W. H. Organizational decision making: Mapping terrains on different planets. In. The Oxford Handbook of Organizational Decision Making, 1, p.1-29, 2008.

HUMMON, N. P. Organizational structures and network processes. Journal of Mathematical Sociology, 15(2), 149 - 161, 1990.

JEN, C, T. The influence of conflict centrality and task interdependency on individual performance and job satisfaction. Intermational Journal of Conflict Management, 24 (2): 126-147, 2013.

KOTTER, J. P. What effective general managers really do. Cambridge. Harvard Business Review, 1982.

KUCKERTZ, A. What's hot in entrepreneurship research? 2013. Available in: https:// entrepreneurship.uni- hohenheim.de/uploads/ media/
What s hot in Entrepreneurship Research 2013 .pdf> Access November, 18, 2013.

KNIGHT, F. H. Risk, Uncertainty and profit (New York: Harper), 1921.

KUHN, T. S. The structure of scientific revolutions (3rd ed.). Chicago: University of Chicago Press, 1996.

KUPPER, D.; BURKHART, T. Effectuation in the context of $R \& D$ projects: Characteristics and impact on project performance. Academy of Management Proceedings, august 1, p.1-6, 2009.

LANDSTROM, H.; BENNER, M. Entrepreneurship research: A history of scholarly migration. In Landstrom, H. e Lohrke, F. Historical Foundations of Entrepreneurship. Edgard Elgar, Northhampton, 2010.

LAKATOS, E. M. Sociology of administration. São Paulo: Atlas, 1997.

LAVIE, D. Alliance portfolios and firm performance: A study of value creation and appropriation in the U.S. software industry. Strategic Management Journal, 28, p.1187-1212, 2007.

LAWRENCE, P. R., LORSCH, J. W. Organization and environment. Boston: Harvard University Press, 1967.

LIMA, A. N.; IMONIANA, J. O. A study on the importance of using management control tools on micro, small and medium-sized industrial enterprises in São Caetano do Sul. Revista da Micro e Pequena Empresa, v. 2, n. 3, p. 28-48, 2008.

MAINE, E.; SOH, P-H., DOS SANTOS. 2014. The role of entrepreneurial decision-making in opportunity creation and recognition. Techno-

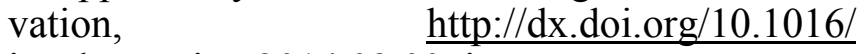
j.technovation.2014.02.007i

MARCH, J. G. The technology of foolishness. In J.G. Marchand J.P. Olsen, eds., Ambiguity and Choice in Organizations. Bergen, Norway: Universitetsforlaget, 1982.

MCEVILY, B.; ZAHEER, A. Bridging ties: A source of firm heterogeneity in competitive capabilities. Strategic Management Journal, 20, p. 1133-1156, 1999.

MELLO, S. C. B.; LEÃO, A. S.; B. PAIVA JR, F. G. Entrepreneurial skills of Brazilian leaders of medium and large companies working in service of the new economy. Revista de Administração Contemporânea, 10 (4), Out./Dez., 2006.

MINTZBERG, H. Patterns in strategy formation. Management Science, 24(9), p. 934-948, 1978.

The fall and rise of strategic planning. Harvard Business Review, JanuaryFebruary, p. 107-114, 1994.

MINTZBERG, H.; QUINN, J. B. The strategy process: concepts, contexts and cases. 3rd ed.Upper Sadlle River: Prentice-Hall, 1996.

MINTZBERG, H.; WATERS, J. A. Tracking strategy in an entrepreneurial firm. Academy 
of Management Journal, p. 465-499, 1982.

Researching the infor-

mation of strategies: The history of Canadian Lady, 1939-1976, in Lamb, R. (ed.) Competitive Strategic Management, Prentice-Hall, Englewood Cliffs, N.J., 1984.

MILLER, J. Access to interorganizational networks as a professional resource. American Sociological Review, 45, p. 479-496, 1980.

MOLINA - MORALES, F. X.; MARTINEZ - FERNANDEZ, T. M. Too much love in the neighborhood can hurt: How an excess of intensity and trust in relationships may produce negative effects on firms. Strategic Management Journal, 30, p. 1013-1023, 2009.

NIEMINEN, J. On centrality in a graph. Scandinavian Journal of Psychology, 15, p. 322 $-336,1974$.

OBSTFELD, D. Social networks, the Tertius lungens and orientation involvement in innovation. Administrative Science Quarterly, 50 (1), p. 100-130, 2005.

OLIVER, C. Determinants of interorganizational relationships: Integration and future directions. Academy of Management Review, 15: 2412651990.

PADULA, A. D.; VADON, Jacques. A global organizational assessment methodology for management consulting in small and medium enterprises. In: Revista de Administração, São Paulo, 31 (1), p. 32-43, jan/mar 1996.

PERRY, J. T.; CHANDLER, J. T.; MARKOVA, G. Entrepreneurial effectuation: A review and suggestions for future research. Entrepreneurship Theory and Practice, july, p. $837-861$, 2012.

PUGH, D. S.; DAVID J. H.; CHRISTOPHER R. H., TURNER, C. Dimensions of organizational structure. Administrative Science Quarterly, 13, p. 65-105, 1968.

PUGH, D. S.; HICKSON, D. J.; HININGS, C. R.; TURNER, C. The context of organization structures. Administrative Science Quarterly, 14, p. 91-113, 1969.

RANSON, S.; HININGS, B.; GREENWOOD, R. The structuring of organizational structures. Administrative Science Quarterly, 25 (1), p. 1-17, 1980.

RATCLIFF, R. E. Banks and corporate lending: An analysis of the impact of the internal structure of the capitalist class on the lending behavior of banks. American Sociological Review, 45, p. 553-570, 1980.

READ, S.; SARASVATHY, S. D. Knowing what to do and doing what you know: Effectuation as a form of entrepreneurial expertise. Joumal of Private Equity, p. $45-62,2005$.

RIBEIRO, E. M, B. A.; BASTOS, A. V. B. Interorganizational social networks in the realization of social projects. Psicol. Soc. [online], 23
(2), p. 282-292, 2011.

RITZER, G. The McDonaldization of society. Journal of American Culture, 6 (1), p. 100-107, 1983.

SABIDUSSI, G. The centrality index of a graph, Psychometrika, 31, p. 581 - 603, 1966.

SARASVATHY, S. D. How do firms come to be? Towards a theory of the prefirm. Unpublished Doctoral Dissertation, Carnegie Mellon University, 1998.

Causation and Effectuation: Towards a theoretical shift from economic inevitability to entrepreneurial contingency. Academy of Management Review, 26, p. 243-288, 2001.

Making it happen: Beyond theories of the firm to theories of firm design. Entrepreneurship: Theory \& Practice, 28(6), p. 519-531, 2004.

SERGEANT, J. R.; FERRES, M. C. Organizational efficiency: A structuralist perspective. Revista de Administração de Empresas, 12 (2), p. 99-110, 1972.

SHANE, S. Reflections on the 2010 AMR decade award: delivering on the promise of entrepreneurship as a field of research. Academy of Management Review, 37 (1), p. 10-20, 2012.

SHANE, S.; VENKATARAMAN, S. The promise of entrepreneurship as a field of research. Academy of Management Review, 25, p. 217226, 2000.

SHAW, M. E. Group structure and the behavior of individuals in small groups. Journal of Psychology, 38, p.139-149, 1954.

SCHEIN, E. Organizational culture and leadership: A dynamic view. San Francisco, $C A$ : Jossey-Bass, 1992.

SCHLÜTER, J.; SCHMITZ, D.; BRETTEL, M.; JARKE, M.; KLAMMA, R. CEUR Proceedings of the 5th International $i^{*}$ Workshop (iStar 2011).

SILVA, C. A. V. Micro and small enterprise cooperation networks: A study of logistics activities in the metallurgical sector of Sertãozinho SP. 2004. 199f. Dissertation (Master degree in Production Engineering) - Escola de Engenharia de São Carlos da Universidade de São Paulo. São Carlos: EESC/USP

SILVA, L. E. P. C. Business strategy and organizational structure under the marketing perspective. Rev. Adm. Empr. Rio de Janeiro, 25 (1), p. 35-51, 1985.

$\mathrm{SOH}, \mathrm{P}-\mathrm{H}$. The role of networking alliances in information acquisition and its implications for new product performance. Joumal of Business Venturing, 18, p. 727-744, 2003.

Network patterns and competitive advantage before the emergence of a dominant design. Strategic Management Journal, 31, p. $438-461,2010$. 
SIMON, H. A. Administrative Behavior (4th expanded edition; first edition 1947), The Free Press, N.Y, 1997.

TASIC, I. A. B., \& ANDREASSI, T. Strategy and entrepreneurship: Decision making and creation under uncertainty. Journal of Operations and Supply Chain Management 1(1), p. 12-23, 2010.

TIWANA, A. Do bridging ties complement strong ties? An empirical examination of alliance ambidexterity. Strategic Management Journal, 29, p. 251-272, 2008.

TSAI, W. Knowledge transfer in intraorganizational networks: Effects of network position and absorptive capacity on business unit innovation and performance. Academy Of Management Journal, 44, p. 996-1004, 2001.

UHRY, R.; BULGACOV, S. Knowledge management and training capacities in banks. RAE-eletrônica, 2 (1), p. 1-22, 2002.

VENKATARAMAN, S. The distinctive domain of entrepreneurship research. In Advances in entrepreneurship, firm emergence and growth, 3, p. 119-138. JAI Press Inc, 1997.

VENKATARAMAN, S.; SARASVATHY, S. Strategy and entrepreneurship: Outlines of an untold story. Darden Business School Working Paper. No. 01-06, 2001.

WASSERMAN, S.; FAUST, K. Social network analysis: methods and applications. Cambridge University Press. Structural analysis in social the social sciences series, 1994.

WEBER, M. The theory of social and economic organizations. Talcott Parsons, ed. New York: Free Press of Glencoe, 1947.

WEICK, K. E. The social psychology of organizing (2nd ed.). Reading, Mass: AddisonWesley, 1979.

WERNERFELT, B. 1984. A resource-based view of the firm. Strategic Management Journal, 5, p. 171-180.

WILTBANK, $R$. ; READ, S.; DEW, N.; \& SARASVATHY, S. D. Prediction and control under uncertainty: Outcomes in angel investing. Journal of Business Venturing, 24, p. $116-133$, 2009.

WOERTMAN, S. The impact of networks on effectuation over causation processes. Master Thesis Business Administration, 2014. Available in < http://essay.utwente.nl/64454/1/ Woertman MA MB.pdf $>$ Accessed in: march, 03. 2014.

ZAHRA, S. A. Technology strategy and new venture performance: A study of corporate sponsored and independent biotechnology ventures. Journal of Business Venturing, 11, p. 289321, 1996.

ZAHRA, S.; WRIGHT, M. Entrepreneurship's next act. Academy of Management Perspectives, November: p. 67-83, 2011. 